\title{
Thalidomide and pentoxifylline block the renal effects of supernatants of macrophages activated with Crotalus durissus cascavella venom
}

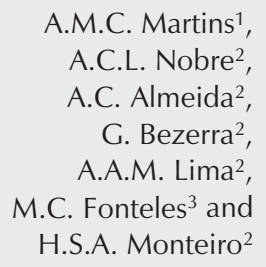

\author{
Departamentos de ${ }^{1}$ Análises Clínicas e Toxicológicas, and \\ ${ }^{2}$ Fisiologia e Farmacologia, Instituto de Biomedicina e \\ Unidade de Pesquisas Clínicas, Universidade Federal do Ceará, \\ Fortaleza, CE, Brasil \\ ${ }^{3}$ Departamento de Fisiologia, Universidade Estadual do Ceará, \\ Fortaleza, CE, Brasil
}

\section{Correspondence}

H.S.A. Monteiro

Unidade de Pesquisas Clínicas

Departamento de Fisiologia e

Farmacologia

Faculdade de Medicina, UFC

Caixa Postal 3229

60420-970 Fortaleza, CE

Brasil

Fax: +55-85-281-5212

E-mail: martinsalice@hotmail.com

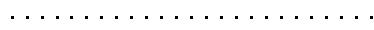

Received September 10, 2003 Accepted June 17, 2004

\section{Abstract}

Because thalidomide and pentoxifylline inhibit the synthesis and release of tumor necrosis factor- $\alpha$ (TNF- $\alpha$ ), we determined the effect of these drugs on the renal damage induced by supernatants of macrophages activated with Crotalus durissus cascavella venom in order to identify the role of TNF- $\alpha$ in the process. Rat peritoneal macrophages were collected with RPMI medium and stimulated in vitro with C.d. cascavella venom $(10 \mu \mathrm{g} / \mathrm{ml})$ in the absence and presence of thalidomide $(15 \mu \mathrm{M})$ or pentoxifylline $(500 \mu \mathrm{M})$ for $1 \mathrm{~h}$ and washed and kept in culture for $2 \mathrm{~h}$. Supernatant $(1 \mathrm{ml})$ was tested on an isolated perfused rat kidney ( $\mathrm{N}=6$ for each group). The first 30 min of each experiment were used as control. The supernatant was added to the perfusion system. All experiments lasted $120 \mathrm{~min}$. The toxic effect of the preparation of venom-stimulated macrophages on renal parameters was determined. At $120 \mathrm{~min}$, thalidomide (Thalid) and pentoxifylline $(\mathrm{Ptx})$ inhibited $(\mathrm{P}<0.05)$ the increase in perfusion pressure caused by the venom $($ control $=114.0 \pm 1.3$; venom $=137.1$ \pm 1.5 ; Thalid $=121.0 \pm 2.5 ; \mathrm{Ptx}=121.4 \pm 4.0 \mathrm{mmHg}$ ), renal vascular resistance (control $=4.5 \pm 0.2$; venom $=7.3 \pm 0.6$; Thalid $=4.5 \pm 0.9$; Ptx $=4.8 \pm 0.6 \mathrm{mmHg} / \mathrm{ml} \mathrm{g}^{-1} \mathrm{~min}^{-1}$ ), urinary flow (control $=0.23 \pm$ 0.001 ; venom $=0.44 \pm 0.01$; Thalid $=0.22 \pm 0.007 ; \mathrm{Ptx}=0.21 \pm 0.009$ $\mathrm{ml} \mathrm{g}^{-1} \mathrm{~min}^{-1}$ ), glomerular filtration rate (control $=0.72 \pm 0.06$; venom $=1.91 \pm 0.11 ;$ Thalid $=0.75 \pm 0.04 ;$ Ptx $\left.=0.77 \pm 0.05 \mathrm{ml} \mathrm{g}^{-1} \mathrm{~min}^{-1}\right)$ and the decrease in percent tubular sodium transport (control $=77.0 \pm 0.9$; venom $=73.9 \pm 0.66$; Thalid $=76.6 \pm 1.1 ;$ Ptx $=81.8 \pm 2.0 \%$ ), percent tubular chloride transport $($ control $=77.1 \pm 1.2$; venom $=71.4 \pm 1.1$; Thalid $=77.6 \pm 1.7 ; \mathrm{Ptx}=76.8 \pm 1.2 \%$ ), and percent tubular potassium transport (control $=72.7 \pm 1.1$; venom $=63.0 \pm 1.1$; Thalid $=72.6 \pm$ $1.0 ; \mathrm{Ptx}=74.8 \pm 1.0 \%), 30 \mathrm{~min}$ before and during the stimulation of macrophages with C.d. cascavella venom. These data suggest the participation of TNF- $\alpha$ in the renal effects induced by supernatant of macrophages activated with C.d. cascavella venom.
Key words

- Nephrotoxicity

- Crotalus durissus cascavella

- Pentoxifylline

- Thalidomide

- Macrophage 


\section{Introduction}

Snakebites are an important public health problem in Brazil. The genus Crotalus contains several species of snakes responsible for high morbidity and mortality rates (1). Crotalus durissus cascavella is a snake usually found in the scrubland of the Brazilian Northeast (2). Crotalic venom causes neurotoxicity, systemic myotoxicity, edematogenic reactions, platelet aggregation, and acute renal failure. The most common complication observed in lethal snakebite victims in Brazil is acute renal failure (3), a process that can occur even after specific antivenom treatment. The pathogenesis of acute renal failure after snakebites appears to be multifactorial (4). Some evidence suggests the possible existence of a direct nephrotoxic agent in the venom, but this does not exclude the release of mediators (5) or rhabdomyolysis as causative agents. Alternatively, these underlying causes can potentiate each other $(6,7)$.

We demonstrated in isolated rat kidney that the venom of C.d. cascavella causes changes in renal function such as increase in perfusion pressure, urinary flow and percent sodium tubular transport (4). We have also reported that macrophages activated by $C . d$. cascavella venom release nephrotoxic mediators (8).

The participation of tumor necrosis factor$\alpha$ (TNF- $\alpha)$ in renal injury has been recently demonstrated (9-11). The protective effect of pentoxifylline against the damage induced by ischemia-reperfusion has been demonstrated in several experimental models $(12,13)$.

The aim of this study was to investigate the action of thalidomide and pentoxifylline on the renal effects induced by supernatants of macrophages activated by C.d. cascavella venom.

\section{Material and Methods}

\section{Macrophage cultures}

Rat peritoneal macrophages were col- lected with RPMI medium 4 days after an injection of $10 \mathrm{ml}$ thioglycolate $(3 \%$, ip) and placed on plastic tissue culture dishes, as previously described (14). After incubation at $37^{\circ} \mathrm{C}$ in a $5 \% \mathrm{CO}_{2}$ atmosphere for $1.5 \mathrm{~h}$, the nonadherent cells were removed by washing the dishes three times with RPMI medium. The cell pattern was determined by cell morphology analysis with a light microscope. The total cells (95\% macrophages) were incubated at $37^{\circ} \mathrm{C}$ in a $5 \% \mathrm{CO}_{2}$ atmosphere for $2 \mathrm{~h}$ in fresh medium (control), and after this period in a medium containing $10 \mu \mathrm{g} / \mathrm{ml}$ C.d. cascavella venom. Thalidomide $(15 \mu \mathrm{M})$ and pentoxifylline $(500 \mu \mathrm{M})$ were added 30 min before the addition of venom and kept in the medium throughout the period of macrophage stimulation with C.d. cascavella venom $(10 \mu \mathrm{g} / \mathrm{ml})$. The supernatant was discarded and, after additional washing, the cells were incubated for $1 \mathrm{~h}$ with $1 \mathrm{ml}$ RPMI medium without venom or drugs. Cell-free incubation medium was obtained by centrifugation for $5 \mathrm{~min}$ and $1 \mathrm{ml}$ of supernatant was adjusted to $1.3 \times 10^{7}$ cells $/ \mathrm{ml}$ and its effects were tested on an isolated rat kidney. Six rats were used in each group of perfusion. Macrophage viability was determined by Trypan blue exclusion as described elsewhere (15). Macrophage viability ranged from 89 to $97 \%$.

\section{Isolated rat kidney}

Adult Wistar rats of both sexes (240-280 g) were fasted with free access to water $24 \mathrm{~h}$ before each experiment. The animals were anesthetized with sodium pentobarbital (50 $\mathrm{mg} / \mathrm{kg}$ body weight). The perfusion fluid was a modified Krebs-Henseleit solution of the following composition: $147 \mathrm{mM} \mathrm{Na}^{+}, 5$ $\mathrm{mM} \mathrm{K}^{+}, 2.5 \mathrm{mM} \mathrm{Ca}^{2+}, 2 \mathrm{mM} \mathrm{Mg}^{2+}, 110 \mathrm{mM}$ $\mathrm{Cl}^{-}, 2.5 \mathrm{mM} \mathrm{HCO}_{3}^{-}, 1 \mathrm{mM} \mathrm{SO}_{4}^{2-}$, and $1 \mathrm{mM}$ $\mathrm{PO}_{4}{ }^{2-}$. Bovine serum albumin (BSA, $6 \mathrm{~g} / 100$ $\mathrm{ml}$; fraction $\mathrm{V}), 0.075 \mathrm{~g}$ urea, $0.075 \mathrm{~g}$ inulin, and $0.15 \mathrm{~g}$ glucose were added to the solution, resulting in a final perfusate volume of 
$100 \mathrm{ml}$. BSA was previously dialyzed for 48 $\mathrm{h}$ at $4^{\circ} \mathrm{C}$ in 1.5 liter of Krebs solution, and the solution was changed after $24 \mathrm{~h}(16,17)$. The $\mathrm{pH}$ was adjusted to 7.4 and the perfusion system, based on Bowman's technique (18), was modified (19) by the addition of an artificial lung to improve oxygenation (20) and of a 1.2-mm Millipore filter (21). Flow calibration and the resistance of the system were determined before each experiment. Perfusion pressure was determined at the tip of the stainless steel cannulae. The right renal artery was cannulated through the upper mesenteric artery and the kidney was isolated (22-24) and submitted to uninterrupted perfusion. After an equilibration period of 15 to $20 \mathrm{~min}$, the experiments were carried out over a total period of time of 120 min. The supernatants of macrophages stimulated with C.d. cascavella venom plus pharmacological inhibitors were added $30 \mathrm{~min}$ after the beginning of the experiment. Perfusion pressure was measured at 5 -min intervals. Urine and perfusate samples were collected every $10 \mathrm{~min}$ for the determination of sodium, chloride, potassium, and inulin levels and osmolality. Sodium and potassium concentrations were determined by flame photometry using a model 445 flame photometer (Instrumentation Laboratory Inc., Lexington, MA, USA) and inulin levels were also determined $(4,18)$. Chloride was determined with a LabTest kit (LabTest Diagnóstica, Lagoa Santa, MG, Brazil). The osmolality of the samples was measured with an Advanced Osmometer (Wescor 5100c, Needham Heights, MA, USA) at vapor pressure.

\section{Drugs}

C.d. cascavella venom was obtained from the regional ophiology laboratory of Fortaleza (LAROF-CE). Thalidomide was obtained from ICN Biomedical Inc., Aurora, $\mathrm{OH}$, USA. Pentoxifylline, RPMI medium, albumin, inulin, and glucose were purchased from Sigma, St. Louis, MO, USA. Thioglycolate was obtained from Difco Laboratories, Detroit, MI, USA.

\section{Statistical analysis}

Data are reported as mean \pm SEM and were analyzed statistically by analysis of variance (ANOVA) followed by the Bonferroni test. The level of significance was set at $\mathrm{P}<0.05$.

\section{Results}

\section{Effect of tumor necrosis factor inhibitors}

Previous results have shown that infusion of the supernatant of macrophages stimulated with C.d. cascavella venom (10 $\mu \mathrm{g} /$ $\mathrm{ml}$ ) after $30 \mathrm{~min}$ of internal control caused alterations of renal function parameters (8). In the present study, thalidomide and pentoxifylline, TNF inhibitors, reversed all the renal changes promoted by the supernatant of macrophages stimulated with C.d. cascavella venom.

The data in Table 1 show that thalidomide $(15 \mu \mathrm{M})$ and pentoxifylline $(500 \mu \mathrm{M})$ inhibited the increase in perfusion pressure, renal vascular resistance, urinary flow, and glomerular filtration rate induced by supernatants of macrophages stimulated with C.d. cascavella venom.

Treatment with thalidomide and pentoxifylline also inhibited the decrease in percent tubular sodium, chloride and potassium transport caused by supernatants of macrophages stimulated with $C$.d. cascavella venom as described in Table 2.

\section{Discussion}

Acute renal failure has been frequently reported after bites of snakes from the Viperidae family (25). Some investigators (5) have reported three possible mechanisms involved in this phenomenon: hemodynamic 
Table 1. Thalidomide and pentoxifylline inhibit the renal effects of the supernatant of macrophages stimulated with Crotalus durissus cascavella venom.

\begin{tabular}{|c|c|c|c|c|}
\hline & RPMI & Venom & $\begin{array}{l}\text { Thalidomide } \\
(15 \mu \mathrm{M})+\text { venom }\end{array}$ & $\begin{array}{c}\text { Pentoxifylline } \\
(500 \mu \mathrm{M})+\text { venom }\end{array}$ \\
\hline \multicolumn{5}{|c|}{$\mathrm{PP}(\mathrm{mmHg})$} \\
\hline 30 & $116.3 \pm 1.8$ & $117.5 \pm 2.2$ & $116.0 \pm 2.2$ & $115.4 \pm 3.3$ \\
\hline 60 & $115.7 \pm 0.8$ & $124.6 \pm 2.9^{*}$ & $119.0 \pm 3.1$ & $121.4 \pm 3.1$ \\
\hline 90 & $117.6 \pm 1.4$ & $137.0 \pm 1.3^{*}$ & $121.0 \pm 4.0$ & $122.0 \pm 5.5$ \\
\hline 120 & $114.0 \pm 1.3$ & $137.1 \pm 1.5^{*}$ & $121.0 \pm 2.5$ & $121.4 \pm 4.0$ \\
\hline \multicolumn{5}{|c|}{$\operatorname{RVR}\left(\mathrm{mmHg} / \mathrm{ml} \mathrm{g}^{-1} \mathrm{~min}^{-1}\right)$} \\
\hline 30 & $4.8 \pm 0.3$ & $4.7 \pm 0.9$ & $4.6 \pm 0.5$ & $4.5 \pm 0.9$ \\
\hline 60 & $4.7 \pm 0.1$ & $6.6 \pm 0.5^{*}$ & $4.6 \pm 0.4$ & $4.6 \pm 1.0$ \\
\hline 90 & $4.4 \pm 0.2$ & $7.1 \pm 0.8^{*}$ & $4.7 \pm 0.6$ & $4.5 \pm 0.8$ \\
\hline 120 & $4.5 \pm 0.2$ & $7.3 \pm 0.6^{*}$ & $4.5 \pm 0.9$ & $4.8 \pm 0.6$ \\
\hline \multicolumn{5}{|c|}{ UF (ml g-1 $\left.\mathrm{min}^{-1}\right)$} \\
\hline 30 & $0.21 \pm 0.05$ & $0.18 \pm 0.001$ & $0.19 \pm 0.009$ & $0.20 \pm 0.003$ \\
\hline 60 & $0.20 \pm 0.01$ & $0.26 \pm 0.03^{*}$ & $0.20 \pm 0.04$ & $0.20 \pm 0.06$ \\
\hline 90 & $0.22 \pm 0.02$ & $0.38 \pm 0.02 *$ & $0.20 \pm 0.006$ & $0.19 \pm 0.013$ \\
\hline 120 & $0.23 \pm 0.01$ & $0.44 \pm 0.01^{*}$ & $0.22 \pm 0.007$ & $0.21 \pm 0.009$ \\
\hline \multicolumn{5}{|c|}{ GFR $\left(\mathrm{ml} \mathrm{g}^{-1} \mathrm{~min}^{-1}\right)$} \\
\hline 30 & $0.76 \pm 0.04$ & $0.72 \pm 0.06$ & $0.77 \pm 0.06$ & $0.79 \pm 0.05$ \\
\hline 60 & $0.79 \pm 0.05$ & $0.95 \pm 0.05$ & $0.73 \pm 0.05$ & $0.82 \pm 0.06$ \\
\hline 90 & $0.70 \pm 0.04$ & $1.41 \pm 0.17^{*}$ & $0.71 \pm 0.05$ & $0.78 \pm 0.06$ \\
\hline 120 & $0.72 \pm 0.06$ & $1.91 \pm 0.11^{*}$ & $0.75 \pm 0.04$ & $0.77 \pm 0.05$ \\
\hline \multicolumn{5}{|c|}{$\begin{array}{l}\text { Macrophages were inoculated with } 10 \mu \mathrm{g} / \mathrm{ml} \text { venom in the presence or absence of } 15 \mu \mathrm{M} \text { thalidomide or } 500 \\
\mu \mathrm{M} \text { pentoxifylline for } 2 \mathrm{~h} \text { at } 37^{\circ} \mathrm{C} \text {. The supernatant was tested on the isolated rat kidney. Data are reported as } \\
\text { means } \pm \mathrm{SEM} \text { for six kidney perfusions carried out for each set of conditions. PP = pentoxyfylline; RVR = } \\
\text { renal vascular resistance; UF = urinary flow; GFR = glomerular filtration rate. } \\
{ }^{*} \mathrm{P}<0.05 \text { compared to other values in the same time group (ANOVA followed by the Bonferroni test). }\end{array}$} \\
\hline
\end{tabular}

alterations, immunologic reactions and direct nephrotoxicity. Some investigators have emphasized the importance of rhabdomyolysis as a cause of acute renal failure after crotalid bites (7), while others have reported nephrotoxicity in the rat isolated kidney after administration of crotalid venom $(4,26)$.

Perfusion of the isolated kidney has been extensively used as a model to study the vascular effect of biologically active substances, preventing the interference of bloodborne cells, hormones and other factors with renal function transported by blood (16).

We have recently demonstrated the renal effect of the supernatant of macrophages activated with C.d. cascavella venom (8). Acting as alarm cells, macrophages signal the presence of foreign bodies by elaborating and releasing several substances, including cyto- kines and arachidonic acid metabolites (27).

An increase in serum TNF- $\alpha$ levels has been reported to occur in mice injected with Bothrops asper and B. jararaca snake venom (28). It has been recently demonstrated that renal cells can produce and release TNF- $\alpha$ (29) and that the kidney is highly sensitive to this cytokine. Hence, it is plausible to relate this protein to the renal damage associated with envenomation or other inflammatory stimuli, as reported by other investigators $(9,10)$.

It has been observed that pentoxifylline can regulate calcium homeostasis (30) and thalidomide can affect the proliferation of endothelial cells and the expression of alpha-beta 3 integrin on the surface of endothelial cells (31). Thalidomide inhibits TNF$\alpha$ synthesis by degrading the mRNA for this 
Table 2. Thalidomide and pentoxifylline inhibit the renal tubular effects of the supernatant of macrophages stimulated with Crotalus durissus cascavella venom.

\begin{tabular}{ccccc}
\hline & RPMI & Venom & $\begin{array}{c}\text { Thalidomide } \\
(15 \mu \mathrm{M})+\text { venom }\end{array}$ & $\begin{array}{c}\text { Pentoxifylline } \\
(500 \mu \mathrm{M})+\text { venom }\end{array}$ \\
\hline$\% \mathrm{TNa}^{+}$ & & & & \\
30 & $80.0 \pm 1.8$ & $80.2 \pm 0.8$ & $79.5 \pm 2.5$ & $83.6 \pm 2.0$ \\
60 & $79.0 \pm 1.2$ & $74.4 \pm 2.5^{*}$ & $76.6 \pm 1.7$ & $85.9 \pm 1.0$ \\
90 & $77.0 \pm 1.0$ & $73.6 \pm 1.0^{*}$ & $77.4 \pm 0.9$ & $83.6 \pm 1.0$ \\
120 & $77.0 \pm 0.9$ & $73.9 \pm 0.6^{*}$ & $76.6 \pm 1.1$ & $81.8 \pm 2.0$ \\
$\% \mathrm{TCl}^{-}$ & & & & \\
30 & $79.5 \pm 1.2$ & $78.1 \pm 1.3$ & $78.4 \pm 2.5$ & $77.6 \pm 1.0$ \\
60 & $77.9 \pm 1.5$ & $73.2 \pm 2.1^{*}$ & $76.7 \pm 1.8$ & $75.9 \pm 1.5$ \\
90 & $76.9 \pm 1.5$ & $72.6 \pm 1.5^{*}$ & $76.9 \pm 1.9$ & $76.8 \pm 1.2$ \\
120 & $77.1 \pm 1.2$ & $71.4 \pm 1.1^{*}$ & $77.6 \pm 1.7$ & \\
$\% \mathrm{TK}^{+}$ & & & & $74.6 \pm 1.2$ \\
30 & $73.2 \pm 1.3$ & $74.1 \pm 1.3$ & $75.4 \pm 1.3$ & $73.6 \pm 1.5$ \\
60 & $72.9 \pm 1.4$ & $73.2 \pm 2.1$ & $74.7 \pm 1.2$ & $74.8 \pm 1.0$ \\
90 & $71.5 \pm 1.2$ & $64.8 \pm 1.5^{*}$ & $73.9 \pm 1.5$ & \\
120 & $72.7 \pm 1.1$ & $63.0 \pm 1.1^{*}$ & $72.6 \pm 1.0$ & \\
\hline
\end{tabular}

Macrophages were inoculated with $10 \mu \mathrm{g} / \mathrm{ml}$ venom in the presence or absence of $15 \mu \mathrm{M}$ thalidomide or 500 $\mu \mathrm{M}$ pentoxifylline for $2 \mathrm{~h}$ at $37^{\circ} \mathrm{C}$. The supernatant was tested on the isolated rat kidney. Data are reported as means \pm SEM for six kidney perfusions carried out for each set of conditions. $\% \mathrm{TNa}^{+}=$percent tubular sodium transport; $\% \mathrm{TCl}^{-}=$percent tubular chloride transport; $\% \mathrm{TK}^{+}=$percent tubular potassium transport. ${ }^{*} \mathrm{P}<0.05$ compared to other values in the same time group (ANOVA followed by the Bonferroni test).

cytokine (29). Thalidomide and pentoxifylline blocked the synthesis and release of TNF- $\alpha$ from macrophages in culture after the same period of incubation and concentration as used in our experiments (12). Using a similar approach, it was demonstrated that thalidomide and pentoxifylline alone did not modify the functional parameters of the kidney (32).

In some situations, receptor-mediated events induced by TNF- $\alpha$ or Fas (apoptosismediating surface antigen fas; CD95) may play a role in apoptosis in acute renal failure (33). Recently, it was demonstrated that pentoxifylline may exert a protective effect against ischemic acute renal failure by inhibiting TNF- $\alpha$ production in rabbits (34).

In the present study, thalidomide and pentoxifylline reversed all renal alterations induced by the supernatants of macrophages stimulated with C.d. cascavella venom. Our findings suggest that thalidomide and pentoxifylline inhibit the release of renal cytotoxic mediators by macrophages activated with C.d. cascavella venom, and indicate the need for investigation of the possible participation of TNF- $\alpha$ in this process. The results also support the need for investigations of the possible use of these drugs in the treatment of snakebites.

\section{References}

1. Santoro MC, Sousa-e-Silva MC, Gonçalves RL, Almeida-Santos SM, Cardoso DF, Laporta-Ferreira IL, Saiki M, Peres CA \& Sano-Martins $S$ (1999). Comparison of the biological activities in venoms from three subspecies of the South American rattlesnake (Crotalus durissus terrificus, C. durissus cascavella and $C$. durissus collilineatus).
Comparative Biochemistry and Physiology. Part C: Pharmacology and Endocrinology, 122: 61-73.

2. Barraviera B (1989). Curso sobre acidentes por animais peçonhentos: Acidentes por serpente do gênero Crotalus. Arquivo Brasileiro de Medicina, 64: 14-20. 
3. Ribeiro LA, Albuquerque MJ, De Campos VA, Katz G, Takaoka NY, Lebrao ML \& Jorge MT (1998). Deaths caused by venomous snakes in the State of São Paulo: evaluation of 43 cases from 1988 to 1993. Revista da Associação Médica Brasileira, 44: 312-318.

4. Martins AM, Monteiro HS, Junior EO, Menezes DB \& Fonteles MC (1998). Effects of Crotalus durissus cascavella venom in the isolated rat kidney. Toxicon, 36: 1441-1450.

5. Sitprija V \& Chaiyabutr N (1999) Nephrotoxicity in snake envenomation. Journal of Natural Toxins, 8: 271-277.

6. Nancy G, Ahlstrom MD, Luginbuhl MDW \& Tisher MDC (1991). Acute anuric renal failure after pygmy rattlesnake bite. Southern Medical Journal, 84: 783-785.

7. Azevedo-Marques MM, Cupo P, Coimbra TM, Hering SE, Rossi MA \& Laure CJ (1985). Myonecrosis, myoglobinuria and acute renal failure induced by South-American rattlesnake (Crotalus durissus terrificus) envenomation in Brazil. Toxicon, 23: 631-636.

8. Martins AMC, Lima AAM, Toyama MH, Marangoni S, Fonteles MC \& Monteiro HSA (2003). Renal effects of supernatant from macrophages activated by Crotalus durissus cascavella venom: The role of phospholipase $\mathrm{A}_{2}$ and cyclo-oxygenase. Pharmacology and Toxicology, 92: 14-20

9. Ruiz-Ortega M, Ruperez M, Lorenzo O, Esteban V, Blanco J, Mezzano S \& Egito J (2002). Angiotensin II regulates the synthesis of pro-inflammatory cytokines and chemokines in the kidney. Kidney International, 82 (Suppl): 12-22.

10. Kornhauser C, Dubey LA, Gary ME, Perez-Luque EL, Malacara JM \& Vagas-Origen A (2002). Serum and urinary insulin-like growth factor1 and tumor necrosis factor in neonates with and without acute renal failure. Pediatric Nephrology, 17: 332-336.

11. Yoshida N, Ikemoto S, Narita K, Sugimura K, Vada S, Yasumoto R, Kishimoto T \& Nakatani T (2002). Interleukin-6, tumor necrosis factor alpha and interleukin-1B in patients with renal cell carcinoma. Brazilian Journal of Cancer, 86: 1396-1400.

12. Gimenez RT, Navidad Novalvos R, Martinez Onturbe P, Santamaria Solis LV \& Castillo ORJL (1995). Liver damage due to normothermic ischemia and reperfusion in the rat. The effects of pentoxifylline pretreatment. Revista Española de Enfermedades Digestivas, 87: 509-515.

13. Vardareli E, Saricam T, Koken T, Degirmenci T, Aral E \& Erenoglu E (1998). The effect of alpha-tocopherol and pentoxifylline on ischemia-reperfusion induced liver injury in rats. Hepato-Gastroenterology, 45: 1505-1508.

14. Rocha MFG, Soares AM, Flores CA, Steiner TS, Lyerly DM, Guerrant RL, Ribeiro RA \& Lima AAM (1998). Intestinal secretory factor released by macrophages stimulated with Clostridium difficile toxin A: role of interleukin 1b. Infection and Immunity, 66: 4910-4916.

15. Korzeniewski C \& Callewaert DM (1983). An enzyme-release assay for natural cytotoxicity. Journal of Immunological Methods, 64: 313320.

16. Fonteles M, Cohen JJ, Black AJ \& Wertheim SJ (1983). Support of renal kidney function by long-chain fatty acids derived from renal tissue. American Journal of Physiology, 244: 235-246.

17. Hanson RW \& Ballard FS (1968). Citrate, pyruvate and lactate contaminants of commercial serum albumin. Journal of Lipidid Research, 9: 667-668.
18. Bowman $\mathrm{RH}$ (1970). Gluconeogenesis in the isolated perfused rat kidney. Journal of Biological Chemistry, 245: 1604-1612.

19. Fonteles MC, Greenberg RN, Monteiro HSA, Currie MG \& Forte LR (1998). Natriuretic and kaliuretic activities of guanylin and uroguanylin in the isolated perfused rat kidney. American Journal of Physiology, 275 (Part 2): F191-F197.

20. Hamilton RL, Benny NM, Williams MC \& Severin-Ghaus EMA (1974). Simple and inexpensive membrane "lung" for small organ perfusion. Journal of Lipid Research, 15: 182-186.

21. Pegg DE (1971). Vascular resistance of the isolated rabbit kidney. Cryobiology, 8: 431-440.

22. Balhlmann J, Giebisch G \& Ochwadt B (1967). Micropuncture study of isolated perfused rat kidney. American Journal of Physiology, 212: 77-82

23. Nishiitsutji-Uwo GM, Ross BD \& Krebs HA (1967). Metabolic activities of the isolated perfused rat kidney. Biochemical Journal, 103: 852-862.

24. Ross BD (1978). The isolated perfused rat kidney. Clinical Science and Molecular Medicine, 55 (Suppl): 513-521.

25. Burdmann EA, Woronik V, Prado EBA, Abdulkader RC, Saldanha LB, Barreto OCO \& Marcondes M (1993). Snakebite induced acute renal failure: an experimental model. American Journal of Tropical Medicine and Hygiene, 48: 82-88.

26. Monteiro HSA, Da Silva IMSC, Martins AMC \& Fonteles MC (2001). Effects of Crotalus durissus terrificus venom and crotoxin on the isolated rat kidney. Brazilian Journal of Medical and Biological Research, 34: 1347-1352.

27. Laskin DL \& Pendino KJ (1995). Macrophages and anti-inflammatory mediators in tissue injury. Annual Review of Pharmacology and Toxicology, 35: 655-677.

28. Petricevich VL, Teixeira CF, Tambourgi DV \& Gutierrez JM (2000). Increments in serum cytokine and nitric oxide levels in mice in jected with Bothrops asper and Bothrops jararaca snake venoms. Toxicon, 38: 1253-1266.

29. Gormley SM, McBride WT, Armstromg MA, McClean E, MacGowan SW, Campalani G \& McMurray TJ (2002). Plasma and urinary cytokine homeostasis and renal function during cardiac surgery without cardiopulmonary bypass cytokine. Cytokine, 17: 61-65.

30. Szamatowicz J, Laudanski P \& Czygier M (2000). Pentoxifylline and verapamil influence on the phagocytosis of peritoneal macrophages from women with endometriosis. Ginekologia Polska, 71: 10221025

31. Gelati M, Corsini E, Frigerio S, Poll B, Broggi G, Croci D, Silvani A, Boiardi A \& Salmaggi A (2003). Effects of thalidomide on parameters involved in angiogenesis: an in vitro study. Neurooncology, 64: 193-201.

32. Nobre ACL (2003). Efeito da microcistina-LR em rim e intestino isolado e na secreção de insulina. Doctoral thesis, Faculdade de Medicina, Universidade Federal do Ceará, Fortaleza, CE, Brazil.

33. Lieberthal W, Koh JS \& Levine JS (1998). Necrosis and apoptosis in acute renal failure. Seminars in Nephrology, 18: 505-518.

34. Kim YK, Yoo JH, Woo JS, Jung JS, Kim BS \& Kim SY (2001). Effect of pentoxifylline on ischemic acute renal failure in rabbits. Renal Failure, 23: 757-772 